\title{
Morphological Diversity of Complex Thalloid Liverwort Genera of Sri Lanka
}

\author{
N. C. S. Ruklani ${ }^{1}$, S. C. K. Rubasinghe ${ }^{2 *}$ and D. G. Long $^{3}$ \\ ${ }^{1}$ Postgraduate Institute of Science, University of Peradeniya, Peradeniya, Sri Lanka. \\ ${ }^{2}$ Department of Botany, Faculty of Science, University of Peradeniya, Peradeniya, Sri Lanka. \\ ${ }^{3}$ Royal Botanic Garden Edinburgh, 20A, Inverleith Row, Edinburgh, U.K. \\ Accepted November 22, 2015
}

\begin{abstract}
As part of a study initiated to trace the evolutionary relationships and biogeographic affinities of Sri Lankan complex thalloid liverworts, we here present the morphological diversity of Sri Lankan complex thalloid liverworts. This serves as the first detailed taxonomic study of the group in Sri Lanka. Specimens were collected from different geographical regions covering almost all topographic and climatic zones of the country. This study revealed 9 genera of complex thalloid liverworts in Sri Lanka. Based on our collections and identifications we prepared a generic key to Sri Lankan complex thalloid liverworts. Taxonomic descriptions were prepared for all identified genera.
\end{abstract}

Keywords: Liverworts, taxonomy, morphology, Sri Lanka.

\section{INTRODUCTION}

The Democratic Socialist Republic of Sri Lanka, formerly known as Ceylon, is an island in the Indian Ocean with a total land area of $65,610 \mathrm{~km}^{2}$ (Myers, 1990; Meegaskumbura et al., 2002; Daskon and Binns, 2010). This relatively small island claimed by Sir Arthur C. Clark as the "Island jewel of Indian Ocean" lies near the southwestern tip of India and shares the same continental shelf (Weerasooriya, 1988) (Fig. 1A).

Sri Lanka is a tropical country with a diverse topography and climate. Three major climatic zones are identified based on the mean annual precipitation; wet $(2500-5500 \mathrm{~mm}$ of rain per annum), intermediate (1900-2500 mm) and dry (<1900 mm) (Dissanayake, 1991; Zubair, 2002) (Fig. 1C). The major topographical zones distinguished by the elevation include the central highlands (1060-2420 mm), the plains (270-1060 $\mathrm{m})$ and the coastal belt $(0-270 \mathrm{~m})$ (Vithanage, 1970) (Fig. 1B). There is a wide range of ecosystems due to this topographic and climatic heterogeneity of the country and the main types of ecosystems of Sri Lanka include forests, grasslands, aquatic, coastal and marine. These different ecosystems harbor a great variety of genera and species of plants and animals. The Western Ghats of India and Sri Lanka together form a biogeographic unit sharing a high endemism in flora and fauna and is one of the major biodiversity hotspots in the world (Myers, 1990; Meegaskumbura et al., 2002; Bossuyt et al., 2004). Thirty percent of Sri Lankan flowering plants are endemic to the country and nearly $75 \%$ of these occur in the Sinharaja Forest Reserve, a world heritage site designated by UNESCO (Myers, 1990). According to floristic endemism records, $70 \%$ of evergreen trees, $40 \%$ of lianas and $11 \%$ of mosses are endemic to the country (Gunawardene et al., 2007; O'Shea, 2003). Many studies have been carried out on Sri Lankan flowering plants (Murawski et al., 1994; Dayanandan et al., 1999; Rubasinghe et al., 2005). However, the bryophyte flora of Sri Lanka remains poorly studied. The first checklists of bryophytes of Sri Lanka were published by B. A. Abeywickrama in 1978 as compilations of a limited number of literature (Abeywickrama and Jansen, 1978 a and b; Pethiyagoda, 2011; Long and Rubasinghe, 2014; Rubasinghe and Long, 2014). Historical records on Sri Lankan bryophyte collections date back to $18^{\text {th }}$ century (Rubasinghe and Long, 2014; Long and Rubasinghe, 2014; Ruklani and Rubasinghe, 2013).

Almost all the bryophyte collectors in the past were from foreign countries, and a detailed description of these collectors and their studies is given in Rubasinghe and Long (2014). A considerable percentage of bryophytes collected in the past remain in different herbaria throughout the continents and the National Herbarium of Sri Lanka contains only a few specimens (Table 1).

Although many taxonomic refinements have occurred within the past few years based on molecular phylogenetics, most of the specimens in the National Herbarium still bear older synonyms and some remain erroneously identified. There is a general scarcity of literature sources with detailed descriptions on bryophytes in Sri Lanka. 

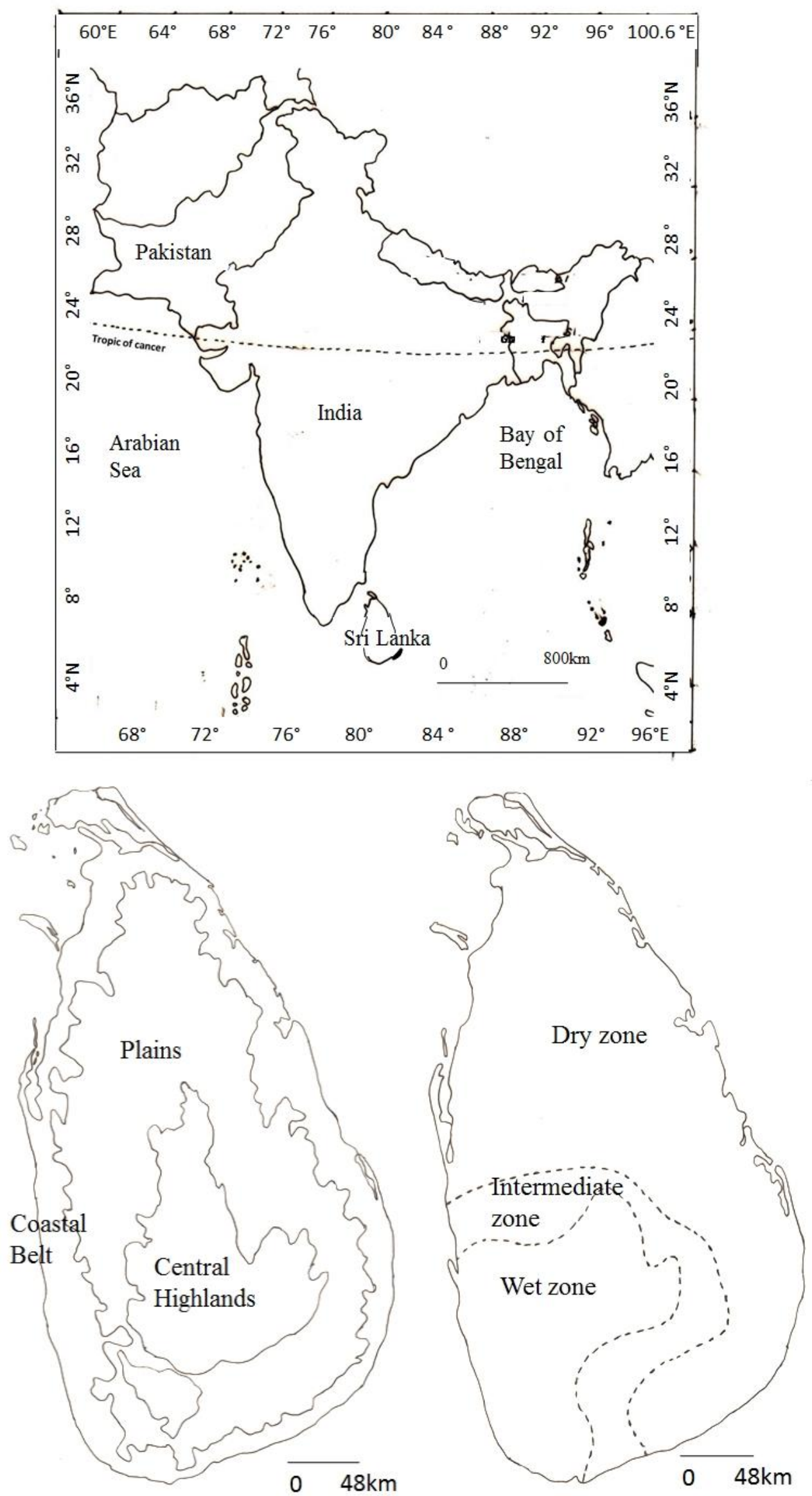

Figure 1. Maps showing (A) the geographic location, (B) topographical zones, (C) climatic zones of Sri Lanka. 
The checklist of mosses of Sri Lanka was updated in 2002 by B.J. O'Shea (O'Shea, 2002). Long and Rubasinghe updated the checklist of liverworts and hornworts of Sri Lanka in 2014. However, there are no records on endemic liverworts and hornworts and these two groups of bryophytes are the least studied groups of bryophytes in Sri Lanka (Gunawardene et al., 2007; Rubasinghe and Long, 2014).The liverwort checklist of Abeywickrama and Jansen (1978 a) includes 16 species of complex thalloids in 9 genera and 4 families (Abeywickrama andJansen, 1978 a). According to the most recently updated checklist of liverworts and hornworts complex thalloids in Sri Lanka consist of 9 families; Aytoniaceae, Blasiaceae, Cyathodiaceae, Dumortieraceae, Exormothecaceae, Lunulariaceae, Marchantiaceae, Ricciaceae and Targioniaceae, 10 genera: Plagiochasma and Reboulia, Blasia, Cyathodium, Exormotheca, Lunularia,Marchantia, Riccia and Targionia and 17 species (Long and Rubasinghe, 2014). Classification of all the liverworts in the earliest checklist (Abeywickrama and Jansen, 1978 a) was based on Evans (1939) where Marchantia, Lunularia, Exormotheca and Dumortiera were included under the broad family Marchantiaceae and Plagiochasma and Reboulia were listed under the family Grimaldiaceae. The genus Cyathodium was included under the family Targioniaceae along with Targionia. There is no record of the genus Blasia in the checklist by Abeywickrama and Jansen (1978 a), although it is mentioned in Long and Rubasinghe (2014) based on the publication of Hattori in 1968 who reported a specimen of Blasia pusilla from Sri Lanka. Complex thalloids recorded in Abeywickrama and
Jansen (1978 a) and Abeywickrama (1959) are based mainly on the literature "Hepaticae Indiae Orientalis" (1860) (Hepatics of Eastern India) by W. Mitten and Species Hepaticarum I (1898-1925) by F. Stephani. Long and Rubasinghe (2014) compiled all the available literature reports of Sri Lankan complex thalloids up to the present. However, there is no Flora for Sri Lankan bryophytes, nor taxonomic descriptions for any of the families, genera or species.

The present study was initiated to evaluate the taxonomy, phylogeny and biogeography of the islands' liverwort and hornwort flora. As a part of this pilot study we aim to present the morphological diversity of Sri Lankan complex thalloid liverworts based on new field collections.

\section{MATERIALS AND METHODS}

Taxon sampling: A thorough literature survey was carried out to trace all past collection sites of complex thalloid liverworts in Sri Lanka. Taxon sampling was made to include all past collection sites as well as new unexplored localities within the country (Fig. 2). Fresh samples were collected along with the substrate using a penknife; wrapped in paper tissues and stored in paper packets prepared according to the Schofield (1985) method. Photographs of the fresh specimens were taken in the field at the time of collection using Nikon D3200 and Nikon D3100 digital cameras.

Table 1. Details of specimens deposited at the National Herbarium, Peradeniya, Sri Lanka.

\begin{tabular}{llll}
\hline \multicolumn{1}{c}{$\begin{array}{c}\text { Name as sited on the } \\
\text { herbarium packet }\end{array}$} & Collector/Specimen number & Year of Collection & Locality \\
\hline $\begin{array}{l}\text { Marchantia palmata } \\
\text { Marchantia } \text { sp. }\end{array}$ & A. H. G. Alston & 1927 & Rangala \\
Marchantia sp. & A. H. G. Alston & 1925 & Near Peradeniya \\
M. lecordiana & M. Fleischer & 1898 & Hantana \\
Lunularia cruciata & M. Fleischer & 1898 & Peradeniya \\
$\begin{array}{l}\text { Dumortiera hirsuta } \\
\text { Plagiochasma rupestre }\end{array}$ & A. H. G. Alston & 1925 & Hakgala \\
Riccia crispatula & A. H. G. Alston Alston & 1925 & Kandy \\
Riccia sp. & G. Gardner & 1925 & Peradeniya \\
\hline
\end{tabular}


Geo-referencing data were recorded using a Garmin Global Positioning System navigator (GPS), along with locality and habitat information, collection and collectors' details. All specimens collected were initially observed using dissecting (Hertel and Reus-Optik Kassel) and light (Eruomex, Arnhem, Holland) microscopes. Observations of detailed cellular characters were made using Olympus CX21FS1 compound microscope and Accu-scope 3025PH-BE-CS Stereomicroscope. Based on the vegetative, reproductive and spore morphological characters observed specimens were identified to their generic/specific level and a taxonomic key was prepared for Sri Lankan complex thalloid liverwort genera. Taxonomic descriptions along with photographs were prepared for all the genera identified.

\section{RESULTS AND DISCUSSION}

A total of 84 specimens of complex thalloids were collected and identified during field excursions. These represented 9 genera of complex thalloid liverworts. A synopsis of complex thalloid liverworts collected is given in Table 2.

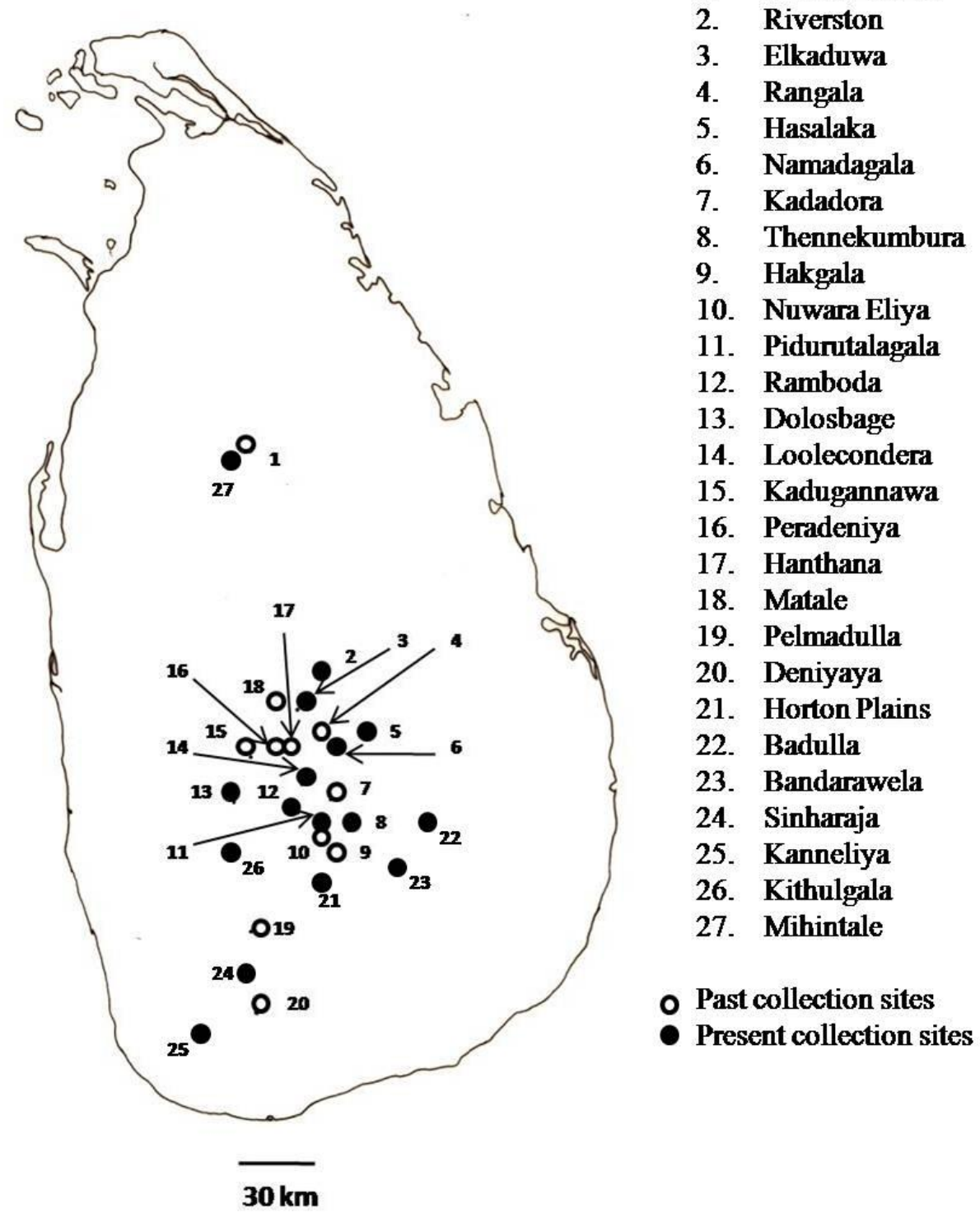

Figure 2. Map of Sri Lanka showing the taxon sampling sites. 
Table 2. Synopsis of complex thalloid liverworts encountered during the present study

\begin{tabular}{|c|c|c|c|}
\hline Order & Family & Genus & Species \\
\hline Lunulariales D.G. Long & $\begin{array}{l}\text { Lunulariaceae H. } \\
\text { Klinggr }\end{array}$ & Lunularia Adans. & $\begin{array}{l}\text { L. cruciata (1.) Dumort. } \\
\text { ex Lindb. }\end{array}$ \\
\hline \multirow[t]{7}{*}{ Marchantiales Limpr. } & $\begin{array}{l}\text { Cyathodiaceae Stotler } \\
\text { and Crand.-Stotl. }\end{array}$ & Cyathodium Kunze & Cyathodium sp. \\
\hline & Marchantiaceae Lindl. & Marchantia L. & $\begin{array}{l}\text { M. paleacea } \text { Bertol. } \\
\text { M. polymorpha } \mathrm{L} \text {. }\end{array}$ \\
\hline & Aytoniaceae Cavers & $\begin{array}{l}\text { Plagiochasma Lehm. } \\
\text { and Lindenb. } \\
\text { Reboulia Raddi }\end{array}$ & $\begin{array}{l}\text { P. rupestre (G.Forst.) } \\
\text { Steph. } \\
R \text {. hemisphaerica (L.) } \\
\text { Raddi }\end{array}$ \\
\hline & Ricciaceae Rchb. & Riccia L. & Riccia sp. \\
\hline & $\begin{array}{l}\text { Exormothecaceae Mu" } \\
\text { ll. Frib. ex Grolle }\end{array}$ & Exormotheca Mitt. & E. ceylonensis Meijer \\
\hline & $\begin{array}{l}\text { Dumortieraceae D. G. } \\
\text { Long }\end{array}$ & Dumortiera Nees & D. hirsuta (Sw.) Nees. \\
\hline & Targioiniaceae Dumort & Targionia L. & T. hypophylla L. \\
\hline
\end{tabular}

\section{Key to Sri Lankan complex thalloid liverwort genera based on gametophytic and sporophytic} characters observed

1. Thallus simple, without dorsiventral differentiation; wing margins "leaf-like" with longitudinally inserted lobes; air chambers and air pores absent; ventral scales without appendages, in two rows on midrib; two types of gemmae present; rhizoids smooth; oil bodies absent or few in unspecialized cells; dioicous; antheridia arranged in two rows, partially embedded dorsally on thallus

Blasia

1. Thallus usually differentiated into layers, air chambers air pores present (rarely absent); ventral scales when presentin 2-10 rows (sometimes absent), usually with appendages; gemmae present or absent, one type if present; rhizoids usually in one or two types, smooth and pegged, specialized oil cells usually present; monoicous or dioicous; antheridia embedded dorsally in thallus or on

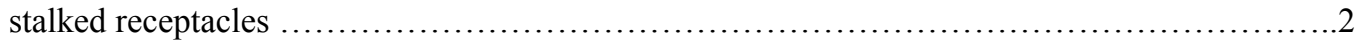

2. Archegonia scattered or loosely aggregated in a dorsal groove, a cavity or a thallus depression, or

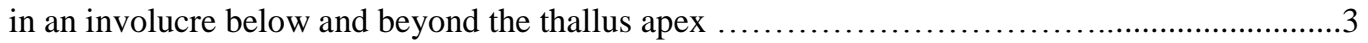

2. Archegonia in well-defined cushions with several archegonial cavities, the cushions developing after fertilization into stalked archegoniophores, or archegonia initiated on ventral side of stalked

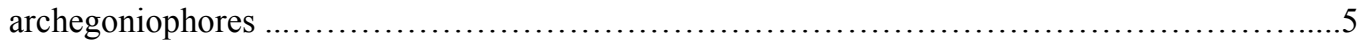

3. Archegonia and sporophytes scattered or in 2-3 rows in dorsal groove, involucres and scales lacking. Antheridia scattered or in a dorsal groove

Riccia

3. Archegonia and sporophytes in an involucre below and beyon $\mathrm{d}$ thallus apex....................4

4. Thallus broadened towards the apex; margin and ventral surface of the thallus without purplish pigmentation, with tubers. Epidermal pores a simple opening among epidermal cells, without hyaline inner ring. Air chambers in 1 layer without chlorophyllose elements. Basal tissue restricted to ventral epidermis or to 1-2 cell layers. Ventral scales small, without or with filiform appendage

Cyathodium

4. Thallus linear; margin and ventral surface of the thallus purplish, without tubers. Epidermal pores bounded by 1-3 concentric rings of cells, with hyaline inner ring. Air chambers in 1 layer, with chlorophyllose filaments. Basal thallus tissue thick. Ventral scales large, with conspicuous, lanceolate-triangular appendage.

Targionia

5. Epidermal pores with 1 ring of differentiated cells, with or without a hyaline inner ring; Epidermal pores strongly elevated above epidermis....

6. Epidermal pores with several concentric rings of cells and a hyaline inner ring, or compound, rarely 
vestigial or absent. ................................................................6

7. Epidermal pores with 1 or several concentric rings of cells. Antheridiophores not produced; ventral

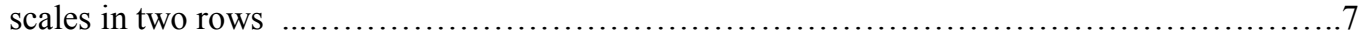

6. Epidermal pores compound, absent or vestigial. Antheridiophores produced. Ventral scales in 2-6

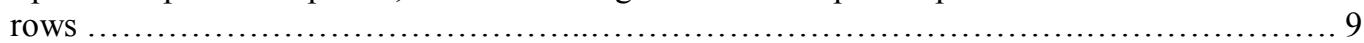

8. Air chambers in 1 layer, with chlorophyllose filaments. Ventral scales with a single, reniform appendage. Gemmae in crescent-shaped (semilunar shaped) gemma cups Lunularia

7. Air chambers in 1 or 2 without chlorophyllose filaments. Ventral scales with 1-4, ovate, lanceolate,

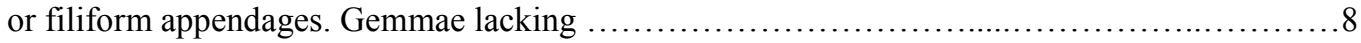

9. Antheridia dorsal, terminal or on small ventral branches, in cushions or in irregular groups, scales few. Archegoniophores terminal, stalk with single rhizoid furrow. Ventral scales with 2 or 3 filiform appendages.

..Reboulia

8. Antheridia in dorsal cushions bounded by conspicuous scales. Archegoniophores dorsal, stalk without rhizoid furrow Ventral scales with 1 or 2 ovate to lanceolate appendages ..Plagiochasma Epidermal pores, and air chambers well developed, the pores compound. Ventral scales large, with 4-6 appendages, laminal scales with or without apical papillae. Bristles lacking. Cup shaped gemma cups produced

Marchantia

9. Epidermal pores, and air chambers absent or vestigial. Ventral scales small, without marginal papillae; no laminal scales. Bristles on ventral side of thallus and male and female receptacles. Gemma cups not produced.

Dumortiera

Taxonomic descriptions for all the specimens identified are given with relevant illustrations according to the order given in Table 2.

\section{Family Lunulariaceae H. Klinggr}

Genus Lunularia Adans., Familles des Plantes 2: 15. 1763.

The gametophytic thalli of Lunularia are yellowish green or green and dichotomously branched, margin often undulated (Fig. 3A). Gemma cups are crescent-shaped (Fig. 3B). Epidermal pores are simple and distinct with5 -7 cells in 3 - 5 rings. Ventral tissue lacks mucilage cavities. Ventral scales are in two rows, hyaline, lunate with a reniform appendage. Antheridia terminal and sessile Archegoniophore receptacle four-lobed, stalk without rhizoid furrows.

Lunularia is the only genus retaining under the family Lunulariaceae (Bischler-Causse et al., 2005; Long, 2006; Crandall-Stotler et al., 2009). The genus is so called because of the lunate shaped gemma cups (in Latin, lunularis = a little moon) (Bischler-Causse et al., 2005; Senning, 2006). Lunularia is a monospecific genus with the single species L. cruciata (L.) Dumort. ex Lindb. and it is recorded from Sri Lanka. Lunularia cruciata has been collected by A. H. G. Alston (1902-1958) from Hakgala Botanic Gardens, Sri Lanka. Lunularia is often associated with human activities and is probably an accidental introduction from Europe.
Family Cyathodiaceae Stotler \& Crand. Stotl. Genus Cyathodium Kunze Novarum et Minus Cognitarum Stirpium Pugillus 6: 17. 1834.

Thalli of Cyathodium are delicate in texture, shiny yellowish green or light green, not tinged with purple, the ventral surface of thalli is whitish, and plants often form incomplete rosettes (Fig. 3C, D and E). Epidermal pores are simple with $5-7$ cells in a single ring. Ventral tissue is reduced. Ventral scales are indistinct, hyaline, with or without appendages. Antheridia are embedded in the thalli. Archegonia are borne in archegonial cavities on the ventral surface near the thallus apex. Sporophyte is protected with a mostly bivalved involucre with a rim of brown pigmented cells (Fig. 3F). Spores are brown, granulate or baculate with an indistinct trilete scar.

The generic name was established in 1834 referring to cyathus which means "cup"; kyathos (ladle or cup) +-odes (similar to), i.e. similar to a cup (Bischler-Causse et al., 2005; Meagher, 2008). Srivastava and Dixit (1996) treat 11 species under the genus in which the two species, Cyathodium cavernarum Kunze and $C$. foetidissimum Schiffn. are pantropical (Salazar Allen and Korpelainen, 2001; Allen et al., 2004; Duckett and Ligrone, 2006) and 8 species are distributed in the Neotropics and Palaeotropics or Asia (Long, 1987; Allen and Korpelainen, 2006). There are two species recorded in Sri Lanka which are $C$. cavernarum and $C$. smaragdinum Schiffn. Ex Keissl (Srivastava and Dixit, 1996; Ruklani and 
Rubasinghe, 2013; Long and Rubasinghe, 2014).Cyathodium cavernarum is not recorded by Abeywickrama and Jansen (1978 a) although it is recorded by Long and Rubasinghe (2014). Srivastava and Dixit (1996) included records of $C$. cavernarum from a temple in Anuradhapura, Sri Lanka. There are no specimens of either two of these species in the National Herbarium (PDN).
Family Marchantiaceae Lindl.

Genus Marchantia L., Species Plantarum 2: 1137. 1753.

The gametophytic thalli of Marchantia species in Sri Lanka are bluish green, yellowish green, green or dark green, sometimes tinged with purple and dichotomously branching (Fig. 4A-F). Epidermal pores compound often with 4 rings of cells with 48 cells.
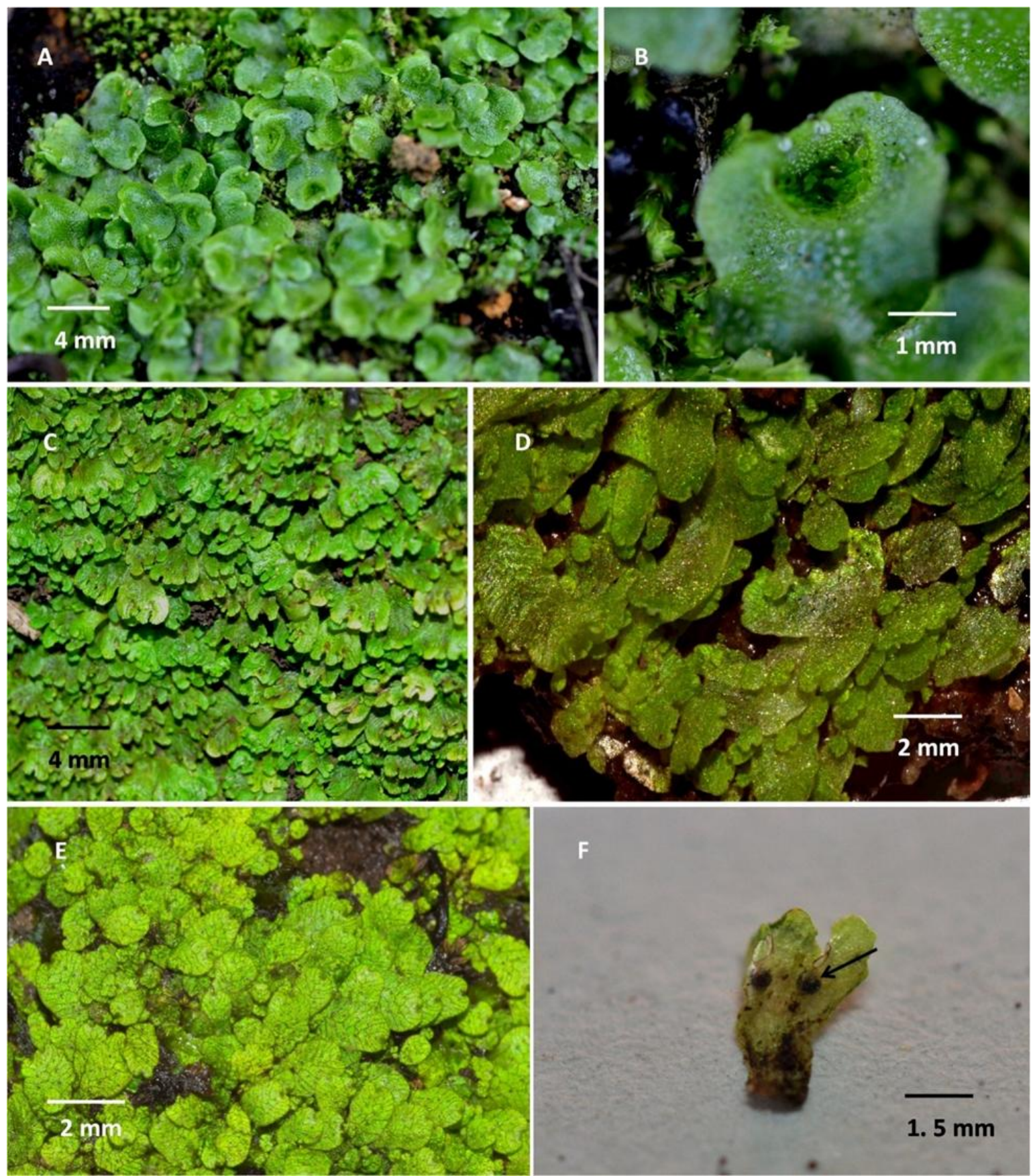

$\mathbf{F}$

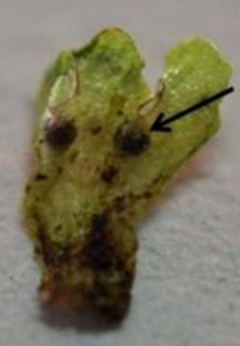

1. $5 \mathrm{~mm}$

Figure 3. Lunularia cruciata (A) Gametophytic thallus (B) Lunate gemma cups with gemmae; Cyathodium sp. $(\mathrm{C}-\mathrm{E})$ Gametophytic thalli (F) Sporophytes on the ventral thallus. 
Inner pore opening round, polygonal, ellipsoid or cruciate. Ventral tissue with or without mucilage cavities. Rhizoids in 2 or 3 types. Ventral scales in 4-6 rows. Median scales with a hyaline, yellow, purplish or pink appendage with or without marginal teeth. Laminal scales with or without apical papillae. Archegoniophore stalked, receptacle symmetrical or asymmetrical, shallowly or deeply divided into terete rays or 4-10 lobes, with or without a median projection (Fig. $5 \mathrm{~A}-\mathrm{E}$ ). Antheridiophore stalked or sessile, receptacle peltate or palmate (Fig. 5F). Involucres alternate with lobes or locate underneath lobes. Spores polymorphic or not. Gemma cups are cup-shaped with entire or ciliate lobes (Fig. 5G).

Marchantia was first published in the first edition of Species Plantarum by Carl von Linnaeus (1707$1778)$ in 1753 introducing 7 species under the genus (Linnaeus, 1753; Evans, 1917): $M$. polymorpha, M. chenopoda, M. cruciate (the basionym of Lunularia cruciata (L.) Dumort.ex Lindb.), M. tenella (basionym of Asterella tenella (L.) P. Beauv.), M. hemisphaerica (basionym of Reboulia hemisphaerica (L.) Raddi), $M$. conica (basionym of Conocephalum conicum (L.) Underw.) and $M$. androgyna (basionym of Mannia androgyna (L.) A. Evans). Among these species only $M$. polymorpha and $M$. chenopoda remain in the genus today (Evans, 1917). There are 36 species under the genus Marchantia with a worldwide distribution (Bischler, 1998; Ho, 2013; Iamonico and Ibertite, 2013).

The genus Marchantia is subdivided into subgenera and sections according to the morphological characters of both gametophyte and sporophyte
(Bischler, 1989) (Fig. 10).

Marchantia species recorded in Sri Lanka represent all the three subgenera: M. polymorpha (subg. Marchantia) (Figs. 4B and 6A), M. paleacea (subg. Chlamidium, sect. Paleaeceae) (Fig. 4A), M. pappeana subsp. robusta, previously known as $M$. robusta (subg. Chlamidium, sect. Chlamidium), $M$. papillata (subg. Chlamidium, sect. Papillatae) and M. acaulis (subg. Protomarchantia, sect. Protomarchantia). Therefore, they are quite distinct from each other in morphology. M. geminata recorded by Abeywickrama and Jansen (1978 a) refers to $M$. acaulis as indicated in Long and Rubasinghe (2014). Both M. amboinensis and $M$. palmata in Abeywickrama and Jansen (1978 a) and Ruklani and Rubasinghe (2013) are synonymized under M. emarginata (Bischler-Causse, 1989; Long and Rubasinghe, 2014). Marchantia linearis in Abeywickrama and Jansen (1978 a) is a misidentification of $M$. papillata subsp. grossibarba (Long and Rubasinghe, 2014).The type specimen of Marchantia robusta was collected in Sri Lanka, however no duplicate exists in the National Herbarium, Peradeniya. According to the literature and data from the National Herbarium, Peradeniya, all records of Sri Lankan Marchantia species are collected from the Central Province and they belong to the collections of A. H. G. Alston (1902 - 1958), M. Fleischer (1861-1930), and F. Schmid (1811-1890). Nomenclature of most herbarium specimens has not been updated to follow the latest classifications and some of them remain as unidentified specimens. Only a limited number of specimens of the recorded species are available at the National Herbarium, Peradeniya (Table 1).

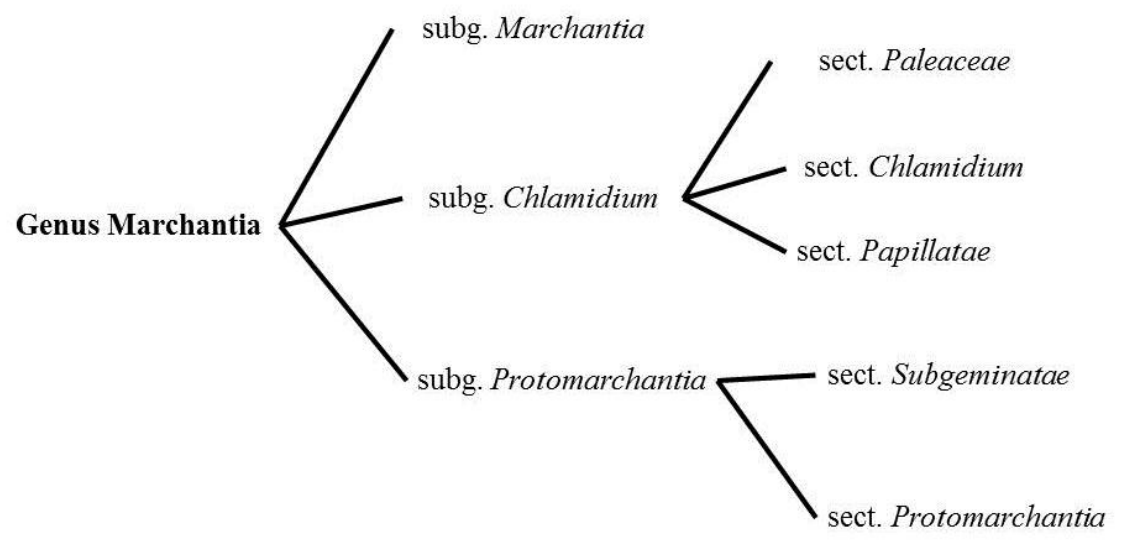

Figure 10. Classification of the genus Marchantia L. based on Bischler, 1989. 

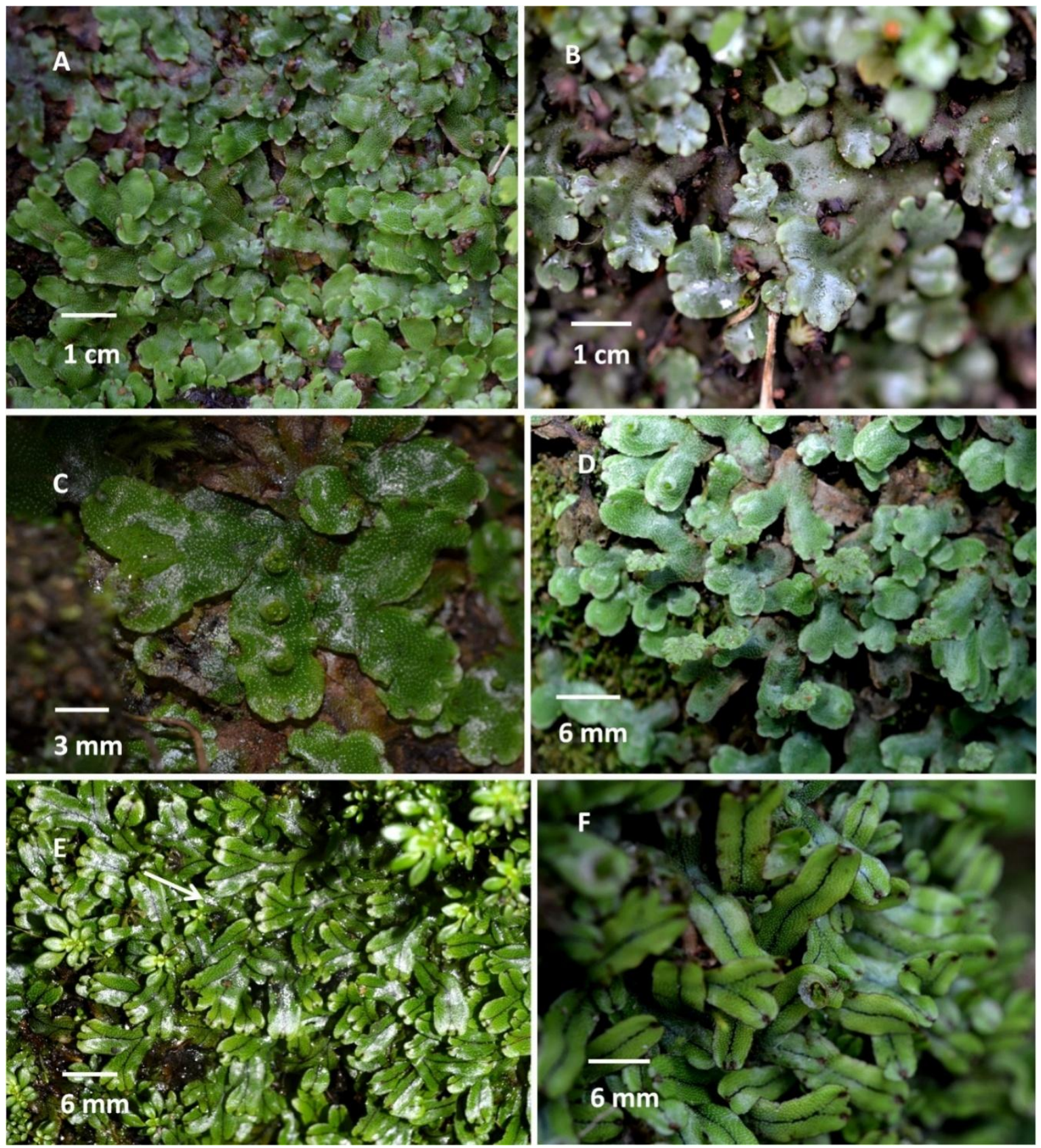

Figure 4. (A) Gametophytic thalli of Marchantia paleacea. (B) Gametophytic thalli of M. polymorpha. (C-F) Different gametophytic thalli morphologies of Marchantia sp.

\section{Family Aytoniaceae Cavers}

Genus Plagiochasma Lehm. \&

Lindenb.,Novarum et Minus Cognitarum

Stirpium Pugillus 4: 13. 1832.

Thallus usually grayish green to green (Fig. 6A, B and $\mathrm{C}$ ).Ventral surface of the thallus often dark purplish. Epidermal pores simple with a single ring of 4 cells. Ventral tissue without mucilage cavities. Ventral scales in two rows with ovate to lanceolate appendages. Appendages light pink to hyaline, not constricted at base. Antheridia dorsal, in cushions along the thallus mid axis (Fig. 6D).
Archegonia dorsal, in cushions. Archegoniophore stalk dorsal, without rhizoid furrows. Sporophyte with globose capsules turning to brown with maturity (Figs. 6E and F). Spores brownish with tuberculate areoles and a distinct trilete marking.

The name Plagiochasma is derived from combination of two Greek terms: "plagios" = lateral, and "chasma" = opening which refers to the bilabiate involucres with lateral dehiscence (Frye and Clark, 1937; Bischler-Causse et al., 2005). According to Bischler-Causse (1979) there are 30 species recognized under the genus. 

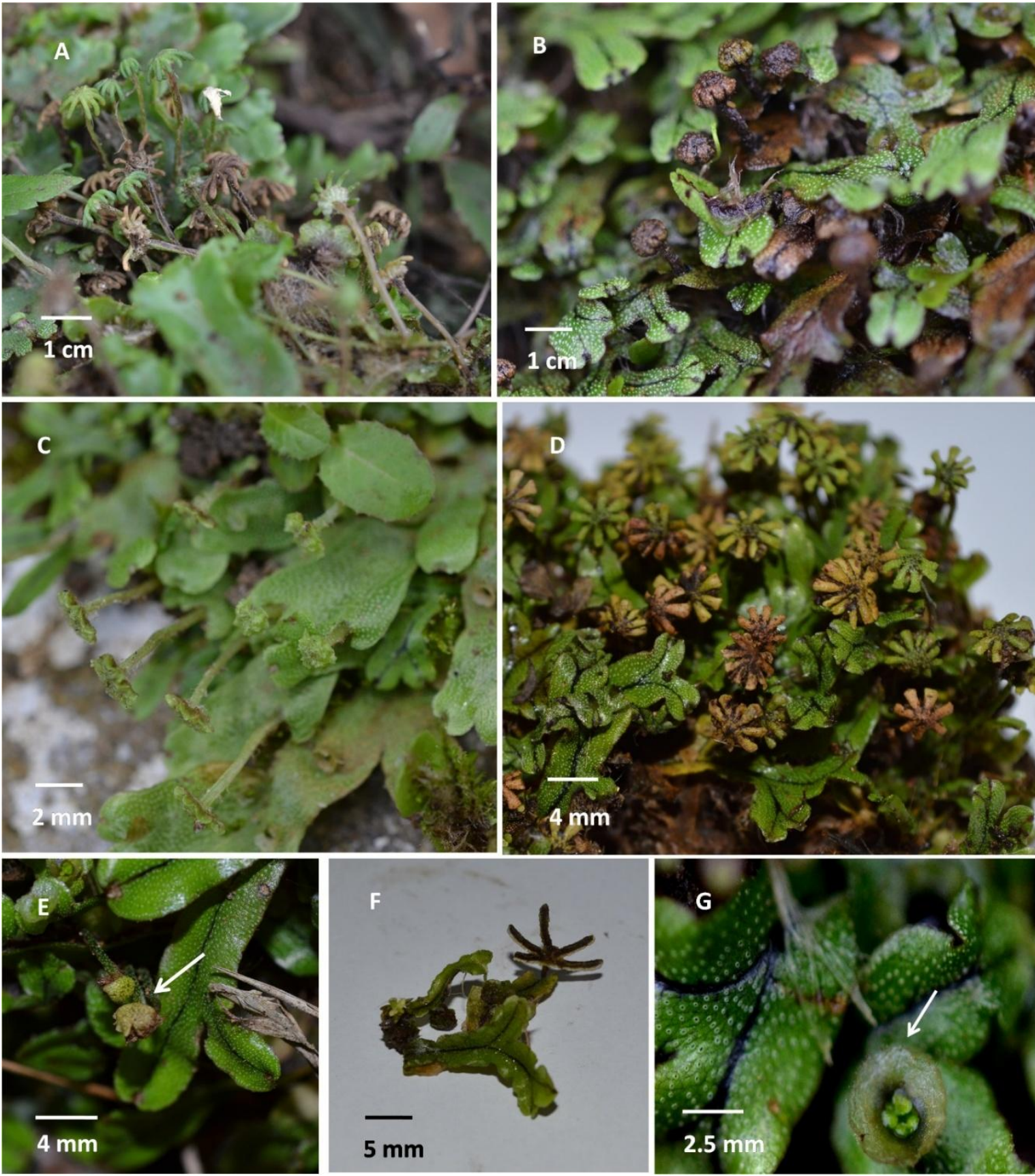

Figure 5. Marchantia sp. (A - E) Different morphologies in female receptacles (F) A male receptacle (G) A gemma cup with gemmae.

There are two subgenera under Plagiochasma: Plagiochasma and Micropylum (Bischler-Causse et al., 2005). Abeywickrama and Jansen (1978 a) have recorded Plagiochasma nepalense as the only recorded species under the genus. Plagiochasma nepalense (Lehm.) Steph., which was first described in Stephani (1898) is now accepted as a synonym under Plagiochasma rupestre (G.Forst.) Steph. (Bischler-Causse, 1979; Bapna and Kachroo, 2000). Plagiochasma rupestre represents the subgen. Micropylum and it is the only species recorded up to date in Sri Lanka (Bapna and Kachroo, 2000; Bischler-Causse et al., 2005; Long and Rubasinghe, 2014). The specimen of Plagiochasma collected by F. Schmid in 1954 from Mount Vernon, Central Province was determined by Sinske Hattori (1915-1992) a Japanese hepaticologist, as $P$. nepalense and a new record for Sri Lanka (Hattori, 1968). In the National herbarium of Sri Lanka all the specimens of Plagiochasma are referred to the synonymous genus Aytonia and they include the collections of A. H. G. Alston only. Aytonia rupestris G. Forst. was the basionym for $P$. rupestre (Stephani, 1898; Alam et al., 2013). 
Genus Reboulia Raddi, Opuscoliscientificid'una Società di professoridella Pontifical Università di Bologna 2: 357. 1818.

Thalli of Reboulia green to dull green in colour, tinged with purple (Fig. 7A-C). Epidermal cells with bulging trigones. Epidermal pores simple, with 5 to 8 cells in 4 or 5 rings, inner opening hexagonal pentagonal or spherical. Air chambers distributed thorough several layers without
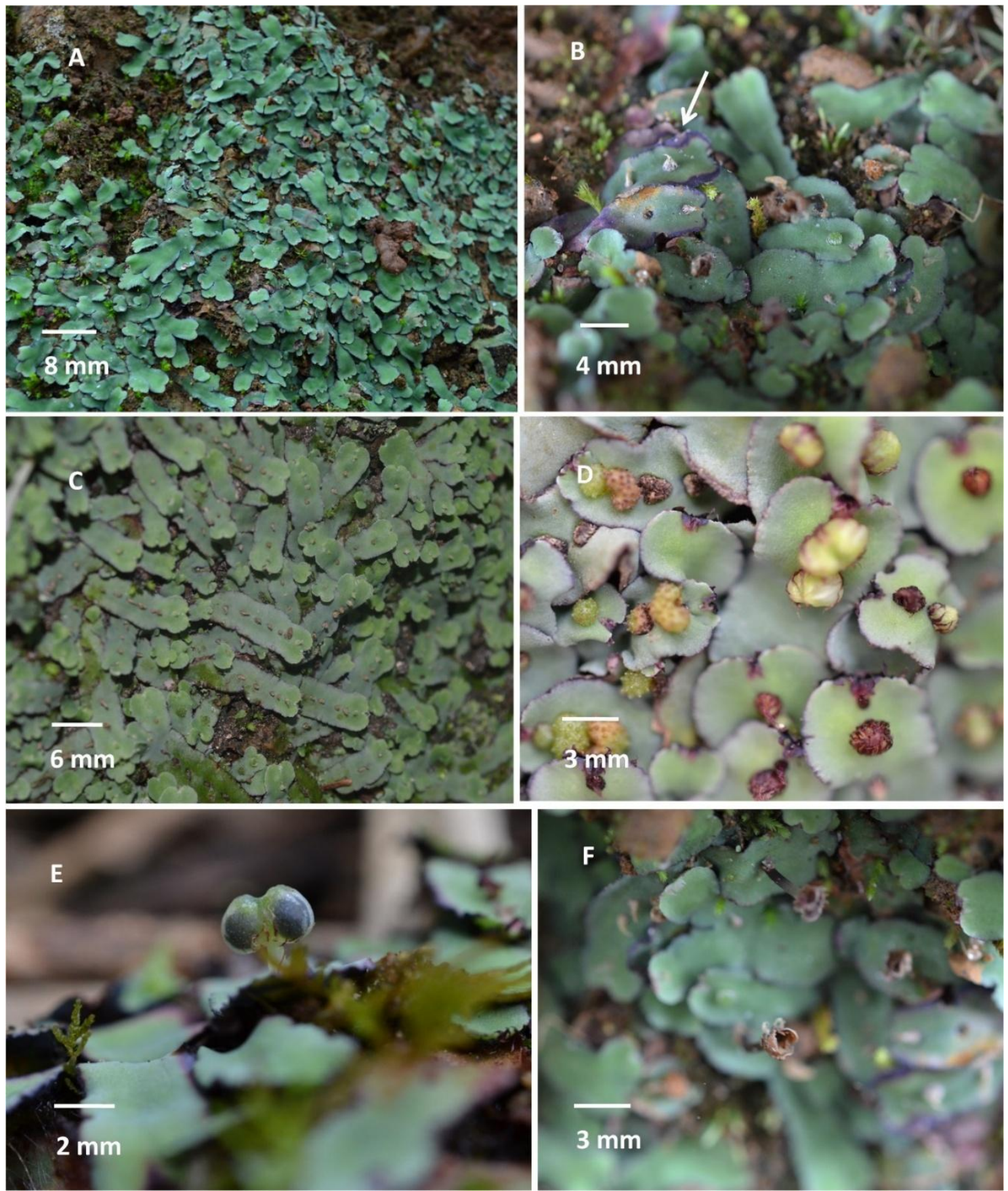

Figure 6. Plagiochasma rupestre (A) A massive population (B) Thallus margins tinged with purple colour (C) Immature gematophytic thalli (D) Antheridia bound by scales (E) Archegoniophore bearing sporophytes (F) Mature archegoniophore. 
The generic name is dedicated by the author to Eugen de Reboul (1781-1851), an Italian botanist from Florence (Little, 1949; Bischler-Causse et al., 2005; Meagher, 2008). The only recorded species in Sri Lanka under the genus is Reboulia hemisphaerica (L.) Raddi, the type of the genus (Bischler, 2004; Bischler-Causse et al., 2005 Long and Rubasinghe, 2014). There are herbarium specimens of Reboulia contributed by A. H. G. Alston in the National Herbarium. Alston's collections of Reboulia are recorded from Hakgala. The collection of M. Onraedt (19041998), who was the first to record $R$. hemisphaerica in Sri Lanka, is not present in the National Herbarium (Onraedt, 1981). However, during the present study the species was collected from several localities.

Family Ricciaceae Rchb.

Genus Riccia L., Species Plantarum 2: 1138. 1753.

Thalli yellowish green, bluish green or green forming rosettes or patches with or without a prominent sulcus dorsally, margin often tinged with purple both dorsally and ventrally (Fig. 7E). Epidermal pores not differentiated. Ventral tissue thick. Ventral scales purplish or hyaline in two rows. Antheridia and archegonia scattered. Sporophyte dorsally or ventrally emerging (Fig. $7 F)$. Spores often brown in colour with or without a distinct trilete scar.

Riccia is the largest genus of Marchantiales comprising about 150 species (Bischler-Causse et $a l ., 2005)$. The generic name is dedicated to Pietro Francesco Ricci, the Italian senator and member of the Botanical Society of Florence (Kolkwitz, 1935; Crum, 1991; Bischler-Causse et al., 2005). The genus Riccia consists of the subgenera: Euriccia, Leptoriccia, Riccia, Ricciella, Thallocarpus. There are 6 species recorded in Sri Lanka under Riccia: R. attenuata Pandé (subgen. Ricciella), R.billardieri Mont. \& Nees (subgen. Euriccia), R.crispatula Mitt., R. discolor Lehm. \& Lindenb. (subgen. Euriccia), R.huebeneriana Lindenb. (subgen. Ricciella) and $R$. sorocarpa Bisch (subgen. Riccia). Abeywickrama and Jansen (1978 a) record only four species under the genus; $R$. crispatula, R.billardieri, $R$. attenuata and $R$. discolor. The type of $R$. crispatula has been collected by the Scottish surgeon-botanist G. Gardner (1810-1849) from Matale, Sri Lanka (Martill et al., 2007; Rubasinghe and Long, 2014) (Table 1).

\section{Family Sematophyllaceae}

Family Exormothecaceae Mu“ Il. Frib.ex Grolle Exormotheca Mitt., Natural History of the Azores, or Western Islands 325. 1870.

Thalli of Exormotheca in Sri Lanka green or whitish green in colour (Fig. 8A, B and C). Epidermal pores are distinct and highly elevated. Air chambers contain chlorophyllose filaments. Ventral tissue with mucilage cavities. Ventral scales hyaline, without appendages. Antheridia are grouped and sunken in the median furrow of the thalli. Archegonia with 2-lobed receptacles, archegoniophore stalk with 1 rhizoid furrow (Fig 8D and E). Spores brown in colour, areolate with tubercules at margin.

The name Exormotheca is derived from "exormos" = extruded, "theca" = capsule, referring to the short-exserted capsules (Bischler-Causse et al., 2005).Willem Meijer (1923 - 2003) was the first person to record a species under Exormotheca in Sri Lanka. In Meijer, (1956) it is mentioned that the specimen was sent to Meijer by Prof Abeywickrama along with some other hepatics for determination. That Exormotheca species had unique characters that deviate from the characters of other species mentioned in Schiffner's monograph of Exormotheca (Meijer, 1956). Therefore Meijer described it as a new species, Exormotheca ceylonensis which is the only recorded species under the genus in Sri Lanka (Fig. 8). Exormotheca ceylonensis is confined to the Western Ghats of India and Sri Lanka and now it is known as a threatened and rare liverwort in India (Udar and Chandra, 1964; Alam et al., 2012). Prof. Abeywickrama has collected Exormotheca from 3 localities in Sri Lanka; Kadugannawa, Hakgala and Kadadora (Meijer, 1956). Hattori, 1968 records E. ceylonensis from two other localities Galagedara and Urugala (Central Province), collected by F. Schmid.

Family Dumortieraceae D. G. Long

Genus Dumortiera Nees, Nova Acta Physicomedica Academiae Caesareae LeopoldinoCarolinae Naturae Curiosorum Exhibentia Ephemeridessive Observationes Historias et Experimenta 12: 410. 1824.

Thalli of Dumortiera dark green in colour with bristles along the margin, dichotomously branched at the apical main thallus (Fig. 9A). Epidermal pores and air chambers absent. Ventral tissue without mucilage cavities. Ventral scales indistinct, small and hyaline, in two rows Antheridiophore with disk shaped receptacles with bristles along the margin and dorsal side, concave at the middle, short stalked or sessile (Fig. 9B). Archegoniophores with 6-9 lobed receptacles with bristles, archegoniophore stalk with two rhizoid furrows (Fig. 9C and D).Spores brown in colour and tuberculate proximally.

The name Dumortiera was dedicated by the author to Count B. C. J. Dumortier (1797- 1878), a Belgian politician and botanist for the specimens 
that had been previously determined as Marchantia hirsuta Sw. (Evans, 1919; BischlerCausse et al., 2005; Gledhill, 2008). There is only one recorded species in Sri Lanka under the genus and that is Dumortiera hirsuta (Sw.) Nees. Evans (1919) mentions that some specimens from Sri Lanka seemed to be different from $D$. hirsuta but looked like D. irrigua (Wilson) Nees. However
Stephani has included D. irrigua among the synonyms under D. hirsuta (Evans, 1919; Santarelli, 1958; Perold, 1993). Hattori (1968) records Dumortiera hirsuta var. nepalensis in the collection of F. Schmid from Kandy (Central Province), Deniyaya (Southern Province) and Pelmadulla (Sabaragamuwa Province).
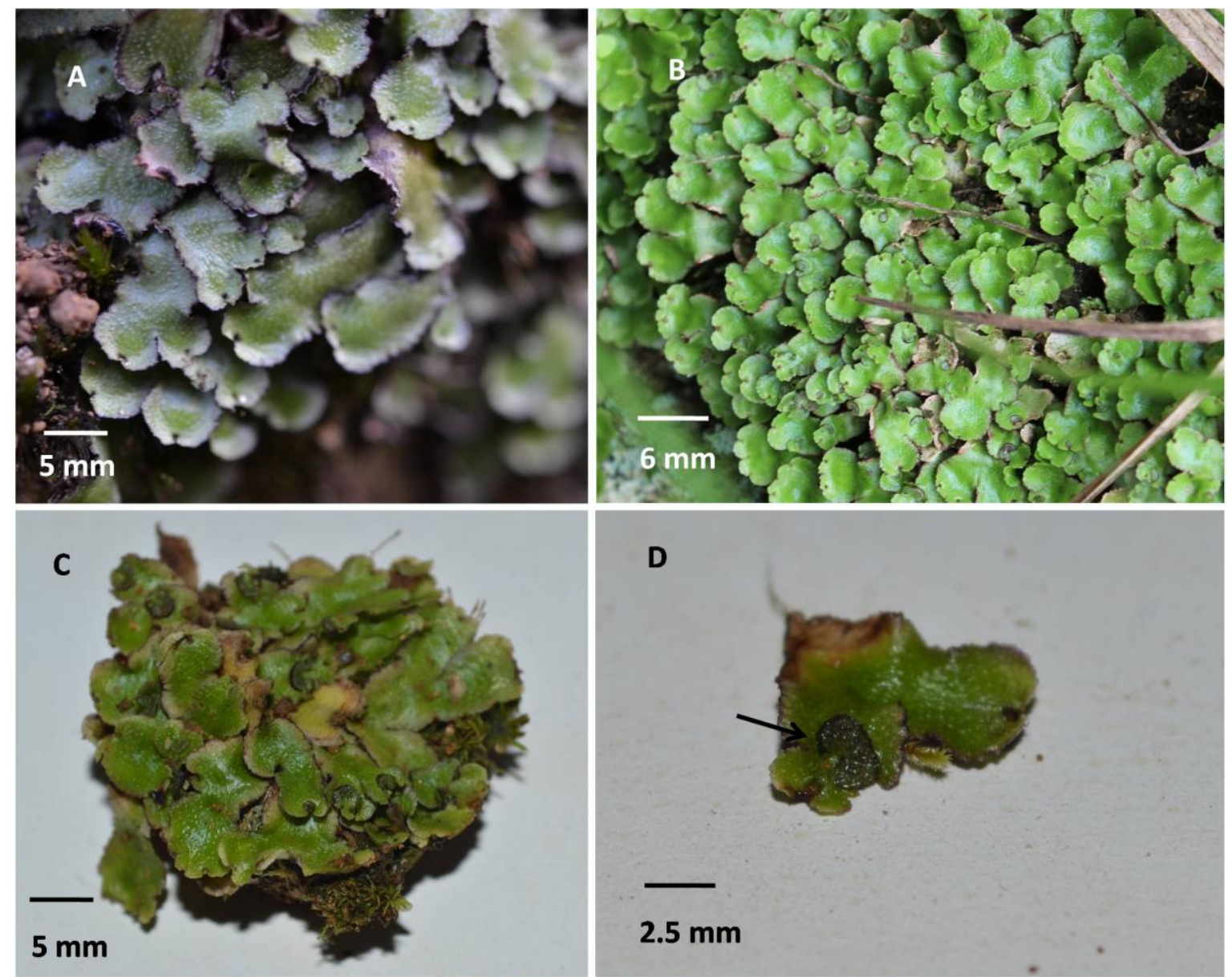

D

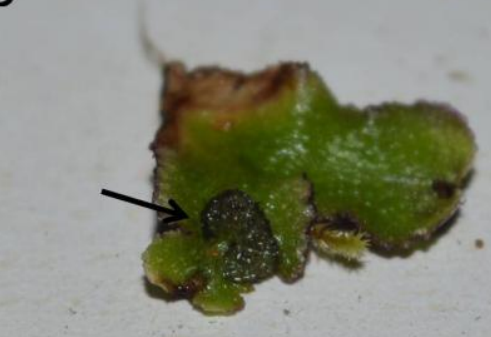

$2.5 \mathrm{~mm}$
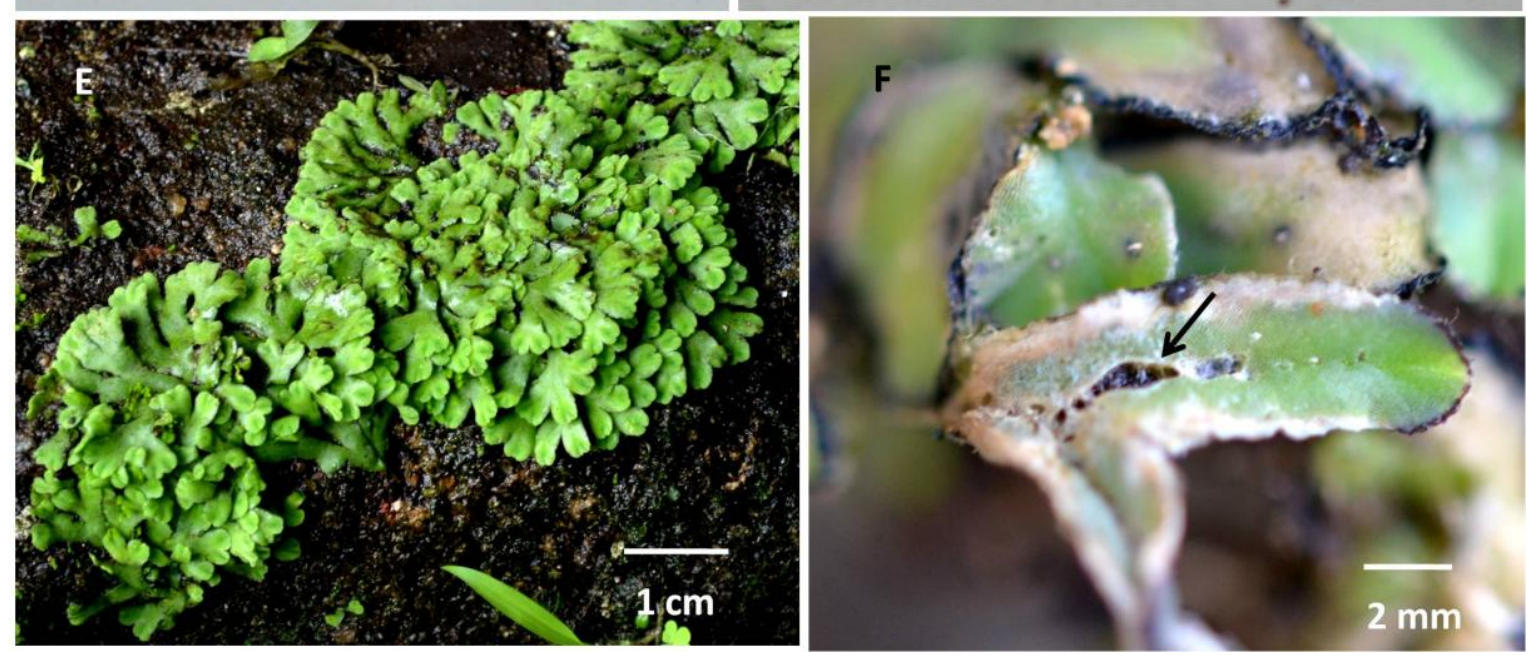

Figure 7. Reboulia hemisphaerica $(\mathrm{A}-\mathrm{C})$. Gametophytic thalli (D) Antheridia in cushions (E) Gametophytic thalli of Riccia sp. (F) Embedded sporophytes on the dorsal thalli of Riccia sp. 
Checklists of Liverworts in Sri Lanka, 1978 and 2014 do not mention any varieties of Dumortiera hirsuta. But it is probable that different varieties of D. hirsuta to occur in the country. The existing herbarium specimens of Dumortiera in the National Herbarium are collections of Alston and G. Gardner (1810-1949) from Kandy district (Table 1).
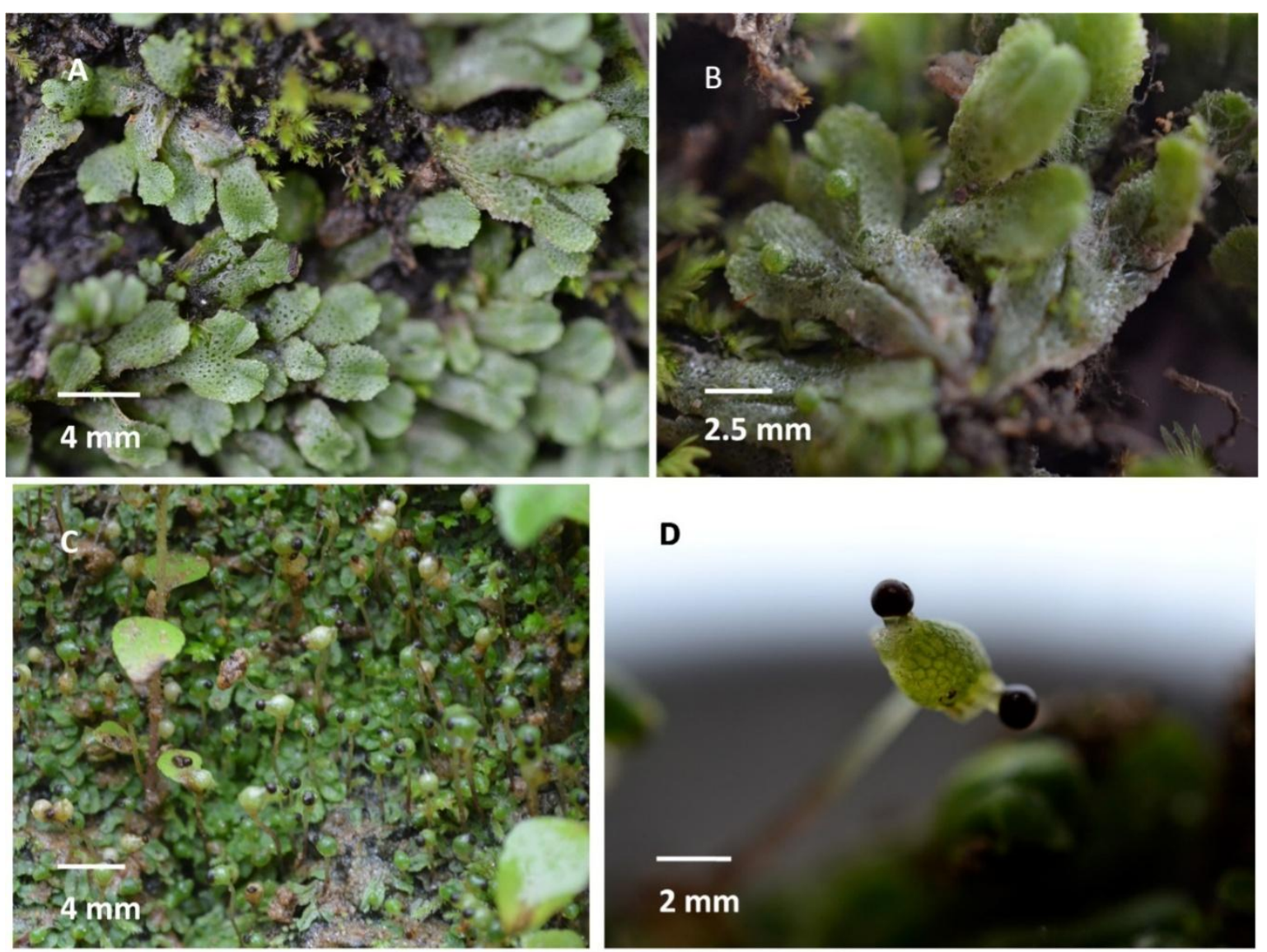

D
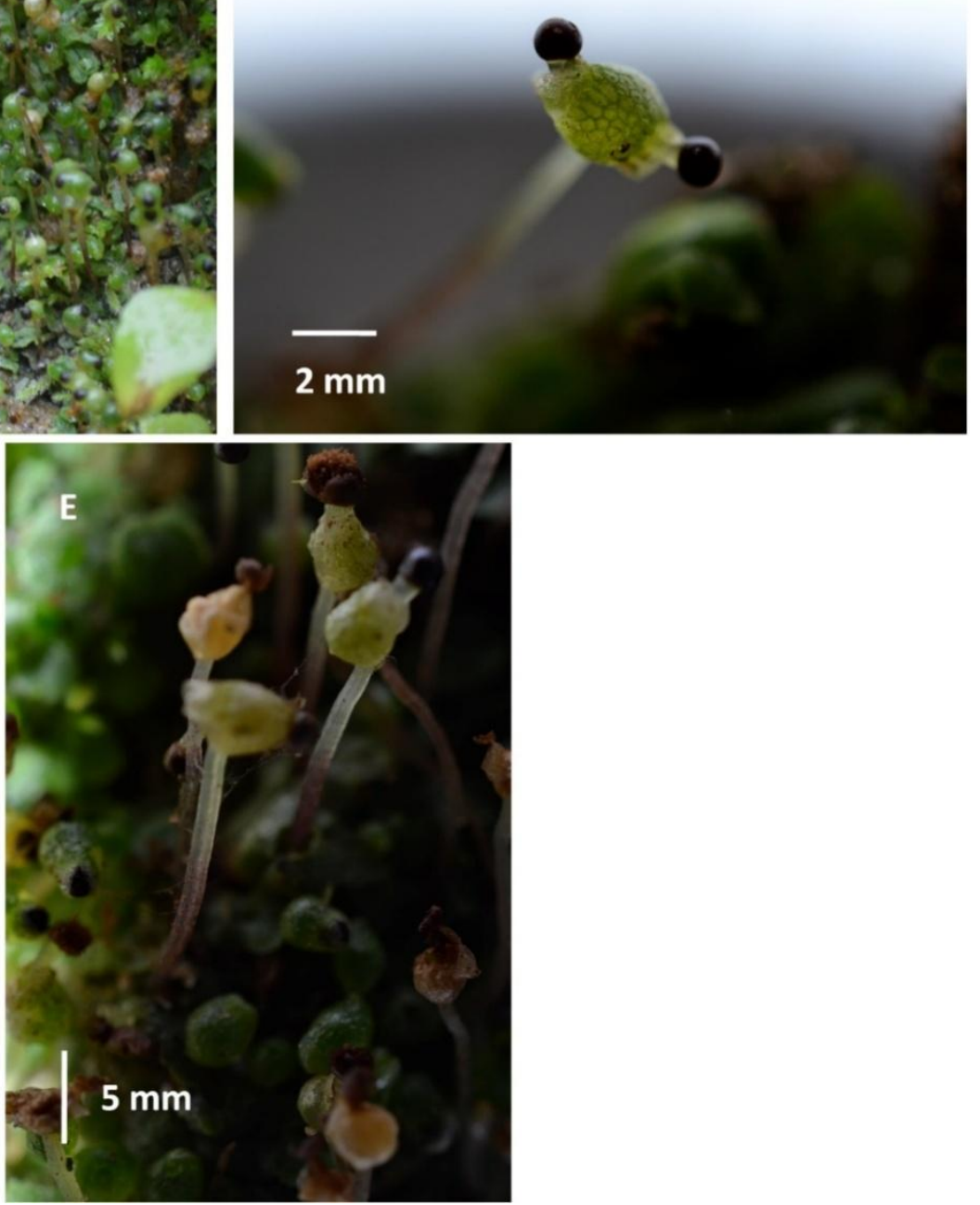

Figure 8. Exormotheca ceylonensis (A-B) Gametophytic thalli (C) A massive sporophyte bearing population (D) Archegoniophore with two sporophytes (E) Mature sporophytes. 
Family Targioiniaceae Dumort.

Genus Targionia L. Species Plantarum 1136. 1753.

Thalli of Targionia is usually dull green in colour with purplish pigmentation along the margin ventrally, thalli dichotomously branched (Fig. 9E). Epidermal pores simple, with 6 to 8 cells in 2 to 3 rings. Ventral scales in two rows, dark purple and hyaline with lanceolate to ovate appendages.
Antheridia dorsal or terminal on main thallus or branches in goups. Archegonia and sporophytes terminal in invloucres on the ventral side of thallus apex (Fig. 9F). Spores brown, with a distinct trilete marking and reticulate areoles and ridges.

Generic name is dedicated to Giovanni TargioniTozzetti (1712-1783), Professor in Florence (Bischler-Causse et al., 2005).
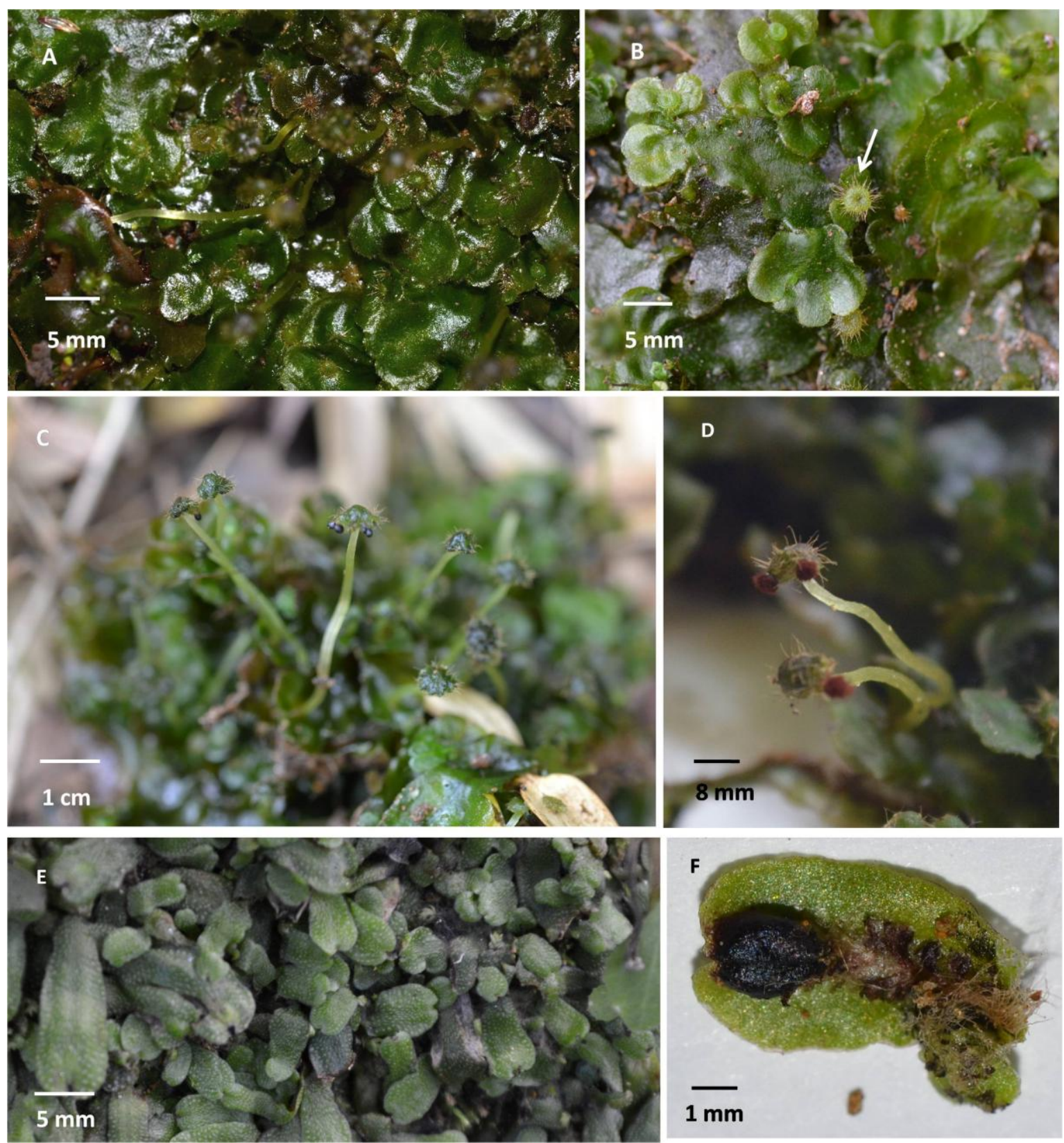
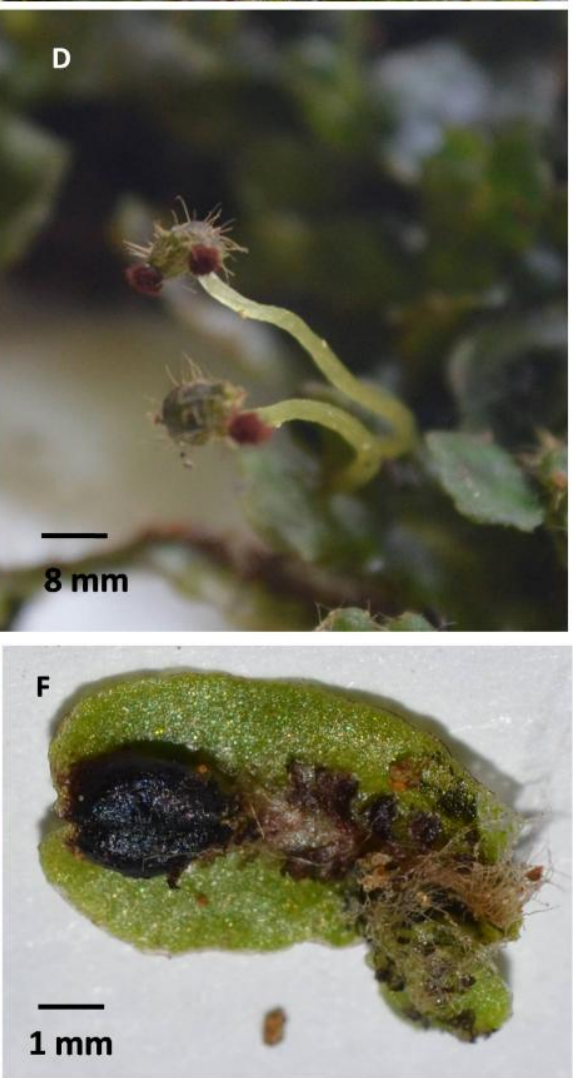

Figure 9. Dumortiera hirsuta (A) Gametophytic thalli (B) Disk shaped antheridia with bristles (C) archegoniophore with several sporophytes (D) Mature sporophytes with split capsules. Targionia hypophylla (E) Gametophytic thalli (F) Mussel-shaped involucres with sporphytes on the ventral side of the thallus apex. 


\section{CONCLUSIONS}

Sir Lankan complex thalloid liverworts remained unexplored since $18^{\text {th }}$ century where A. H. G. Alston, M. Fleischer and G. Gardner have contributed much to the only remaining collections at the National Herbarium, Peradeniya to date. With the aim to initiate research on Sri Lankan complex thalloid liverworts, field excursions were made to localities of these past recorded sites as well as new unexplored localities. Some of the older locality sites (e.g. Kadugannawa, Hakgala and Nuwara Eliya) had been destroyed due to urbanization, deforestation and removal of habitats for cultivation and construction of highways.

Complex thalloids in Sri Lanka show a high morphological diversity that they differ slightly from the taxonomic descriptions of other Asiatic taxa. During the study 8 families, 9 genera and 8 species were identified.

This study will be continued with molecular characterization and evaluation of biogeographic affinities of Sri Lankan liverworts. Threatened species and conservation sites will be proposed.

\section{ACKNOWLEDGMENTS}

Financial support was provided by International Research Center, University of Peradeniya, Sri Lanka (InRC/RG/13/20). The staff at the National Herbarium, Peradeniya is thanked for information on early collectors and their collections at PDN.

\section{REFERENCES}

Abeywickrama, B. A. (1959). The genera of the liverworts of Ceylon. Ceylon Journal of Science (Biological Sciences) 2: 33-81.

Abeywickrama, B. A. and Jansen, M. A. B. (1978 a). A check list of the liverworts of Sri Lanka.UNESCO: Man and the Biosphere National Committee for Sri Lanka Publication 1: $1-10$.

Abeywickrama, B. A. and Jansen, M.A.B. (1978 b). A check list of the mosses of Sri Lanka.UNESCO: Man and the Biosphere National Committee for Sri Lanka Publication 2: 1-25.

Alam, A., Vats, S. and Behera, K. K. (2012). Exormotheca ceylonensis Meijer - a threatened liverwort in India, rediscovered in Palni Hills, Tamil Nadu. Journal of Threatened Taxa 4: 2593-2595.

Alam, A., Sharma, V., Verma, P. K. and Kumar, K. (2013). Scanning electron microscopy of some selected south Indian taxa of Marchantiales (Bryophyta: Hepaticae). Archive for Bryology 190: $1-6$

Allen, N. S., Lépiz, E. and De Gracia, J. E. (2004). Cyathodium foetidissimum (Marchantiales), an asiatic species new to tropical America. The Bryologist 107(1): 41-46.

Bapna, K. R., and Kachroo, P. (2000). Hepaticology in India-II. Himanshu Publication, Udaipur.

Bischler-Causse, H. (1979). Plagiochasma Lehm. and Lindenb. III. Les taxa d'Asie et d'Oceanle. Journal of the Hattori Botanical Laboratory 45: $25-79$.

Bischler-Causse, H. (1989). Marchantia.: The Asiatic and Oceanic taxa. Bryophytorum Bibliotheca 38: 1-317.

Bischler, H. (1998). Systematics and evolution of the genera of the Marchantiales. Bryophytorum Bibliotheca 51: 1-201.

Bischler, H. (2004). Liverworts of the Mediterranean. Bryophytorum Bibliotheca 61: $1-252$.

Bischler-Causse, H., Gradstein, S. R., Jovet-Ast, S. Long, D. G. and Allen, N. S. (2005). Marchantiidae. Flora Neotropica 97: 1-262.

Bossuyt, F., Meegaskumbura, M., Beenaerts, N., Gower, D. J., Pethiyagoda, R., Roelants, K. and Milinkovitch, M. C. 2004. Local endemism within the Western Ghats-Sri Lanka biodiversity hotspot. Science 306 (5695): 479481.

Crandall-Stotler, B., Stotler, R. and Long, D. G. (2009). Phylogeny and classification of the Marchantiophyta. Edinburgh Journal of Botany 66: 1-44.

Crum, H. A. (1991). Liverworts and hornworts of southern Michigan. University of Michigan Herbarium Publisher.

Daskon, C. and Binns, T. (2010). Culture, tradition and sustainable rural livelihoods: exploring the culture-development interface in Kandy, Sri Lanka. Community Development Journal 45(4): 494-517.

Dayanandan, S., Ashton, P. S., Williams, S. M. and Primack, R. B. (1999). Phylogeny of the tropical tree family Dipterocarpaceae based on nucleotide sequences of the chloroplast $r b c \mathrm{~L}$ gene. American Journal of Botany 86(8): 11821190.

Dissanayake, C. B. (1991). The fluoride problem in the ground water of Sri Lankaenvironmental management and health. International Journal of Environmental Studies 38(2-3): 137-155.

Duckett, J. G. and Ligrone, R. (2006). Cyathodium Kunze (Cyathodiaceae: Marchantiales), a tropical liverwort genus and family new to Europe, in Southern Italy. Journal of Bryology 28(2): 88-96. 
Evans, A. W. (1917). The American species of Marchantia. Transactions of the Connecticut Academy of Arts and Sciences. New Haven. Connecticut.

Evans, A. W. (1919). A taxonomic study of Dumortiera. Bulletin of the Torrey Botanical Club 167-182.

Evans, A. W. (1939). The classification of the Hepaticae. The Botanical Review 5(1): 49-96.

Frye, T.C. and Clark, L. (1937). Hepaticae of North America.University of Washington Publications.

Gledhill, D. (2008). The names of plants. Cambridge University Press.

Gunawardene, N. R., Daniels, D. A., Gunatilleke, I. A. U. N., Gunatilleke, C. V. S., Karunakaran, P. V., Nayak, G. K. and Vasanthy, G. (2007). A brief overview of the Western Ghats-Sri Lanka biodiversity hotspot. Current Science 93(11): 1567-1572.

Hattori, S. (1968). Hepaticae collected by F. Schmid in Ceylon and Pakistan. Candollea 23: 287-294.

Ho, B. C. (2013). The Liverwort Genus Marchantia 1 (Marchantiophyta: Marchantiopsida) in Singapore, with a New Species Record. Nature in Singapore 6: 187190.

Kolkwitz, R. (1935). Pflanzenphysiologie: Versuche und Beobachtungen an höheren und niederenPflanzeneinschließlichBakteriologie und HydrobiologiemitPlanktonkunde. J. G. Fischer.

Iamonico, D. and Iberite, M. (2013). Lectotypification of the Linnaean name Marchantia hemisphaerica L. (Aytoniaceae). Cryptogamie, Bryologie 34(1): 89-91.

Linnaeus, C. (1753). Species Plantarum. Stockholm 2: 1137.

Little, E. L. (1949). Nominaconservanda proposals in Hepaticae. The Bryologist.1-22.

Long, D. G. (1987). Hepaticae and Anthocerotae of the Arabian peninsula: studies in Arabian bryophytes 10. Nova Hedwigia 45(1-2): 175195.

Long, D. G. (2006). New higher taxa of complex thalloid liverworts (MarchantiophytaMarchantiopsida). Edinburgh Journal of Botany 63(2-3): 257-262.

Long, D. G. and Rubasinghe, S. C. (2014). Liverworts and hornworts of Sri Lanka: a revised checklist. Ceylon Journal of Science (Biological Sciences) 43(1): 1-36.

Martill, D. M., Bechly, G. and Loveridge, R. F. (2007). The Crato fossil beds of Brazil. Window into an Ancient World.

Meagher, D. (2008). Chapter Twenty-one: An Etymology of Australian Bryophyte Genera. 1Liverworts and Hornworts. Fieldiana Botany. 257-269.
Meegaskumbura, M., Bossuyt, F., Pethiyagoda, R., Manamendra-Arachchi, K., Bahir, M., Milinkovitch, M. C. and Schneider, C. J. (2002). Sri Lanka: an amphibian hot spot. Science 298(5592): 379-379.

Meijer, W. (1956).A new species of Exormotheca from Ceylon.Journal of the Hattori Botanical Laboratory 16: 72-74.

Mitten, W. (1860). Hepaticae Indiae Orientalis: An enumeration of the Hepaticae of the East Indies. Journal of the Proceedings of the Linnean Society of London. Botany 5(18): 89108.

Murawski, D. A., Dayanandan, B. and Bawa, K. S. (1994). Outcrossing rates of two endemic Shorea species from Sri Lankan tropical rain forests. Biotropica 23-29.

Myers, N. (1990). The biodiversity challenge: expanded hot-spots analysis. Environmentalist 10(4): 243-256.

Onraedt, M. (1981). Bryophytes récoltées a Sri Lanka (Ceylan). V. Journal of the Hattori Botanical Laboratory 50: 191-216.

O'Shea, B.J. (2002). Checklist of the mosses of Sri Lanka. Journal of the Hattori Botanical Laboratory 92: 125-164.

O'Shea, B. J. (2003). Biogeographical relationships of the mosses of Sri Lanka. Journal of Hattori Botanical Laboratory 93: 293-304.

Perold, S. M. (1993). Studies in the Marchantiales (Hepaticae) from southern Africa. 1. The genus Dumortiera and D. hirsuta; the genus Lunularia and L. cruciata. Bothalia 23(1): 4957.

Pethiyagoda, U. (2011). Appreciation: Professor B. A. Abeywickrama (1920-2011). Journal of the National Science Foundation of Sri Lanka 39(3): 277-278.

Rubasinghe, S. C. K. and Long, D. G. (2014). Bryophytes of Sri Lanka: a review of past exploration and taxonomic research and priorities for the future. Journal of Bryology 36(4): 259-270.

Rubasinghe, S. C. K., Yakandawala, D. M. D. and Wijesundara, D. S. A. (2005). A preliminary study on species limits of the endemic genus Stemonoporus (Diptherocarpaceae) using morphological data. Proceedings of the Peradeniya University Research Sessions, Sri Lanka, 10.

Ruklani, N. C. S. and Rubasinghe, S. C. K. (2013). A preliminary survey of Bryophytes of the central province of Sri Lanka.Ceylon Journal of Science (Biological Sciences) 42: 67-72.

Salazar Allen, N. and Korpelainen, H. (2006). Notes on neotropical Cyathodium. Cryptogamie. Bryologie 27(1): 85-96.

Santarelli, E. (1958). ContributoAlla Flora Crittogamica Versiliese: Epatiche. Webbia 
14(1): 53-71.

Schofield, W. B. (1985). Introduction to Bryology. McMillen, New York.

Senning, A. (2006). Elsevier's Dictionary of Chemoetymology: The Whys and Whences of Chemical Nomenclature and Terminology. Elsevier.

Srivastava, S. C. and Dixit, R. (1996). The genus Cyathodium Kunze. Journal of the Hattori Botanical Laboratory. 149-215.

Stephani, F. (1898).Bulletin de l'Herbier Boissier 6: 783.

Stephani, F. (1898-1925): Species Hepaticarum 1-

Udar, R. and Chandra, V. (1964). Exormotheca
ceylonensis-New record from India. Current Science 33: 436-438.

Vithanage, P. W. (1970). A study of geomorphology and morphotechtonics of Ceylone.Proceedings of the $2^{\text {nd }}$ seminar on geochemical prospecting methods and techniques. UN Mineral Resources Development Series 38: 391-405.

Weerasooriya, W. (1988). Links between Australia and Sri Lanka: A book about the Sri Lankans in Australia: Colombo Government Press.

Zubair, L. (2002). El Nino-southern oscillation influences on rice production in Sri Lanka. International Journal of Climatology 22(2): 249-260. 